\title{
Filantropi Islam: Zakat Saham di Pasar Modal Syariah Indonesia
}

\section{Islamic Philanthropy: Zakat Share In Indonesian Islamic Capital Market}

\author{
Eja Armaz Hardi \\ Universitas Islam Negeri Sulthan Thaha Saifuddin Jambi \\ email: eja.armaz.hardi@gmail.com \\ Artikel diterima 06 September 2019, diseleksi 26 Mei 2020, \\ dan disetujui 05 Juli 2020
}

Abstrak: Perkembangan kajian filantropi Islam beberapa dekade terakhir telah memberikan kontribusi signifikan terhadap perluasan implemetasi objek zakat. Objek harta kena zakat menjadi fokus diskusi oleh beberapa sarjana, lembaga sosial keagamaan, dan pemerintah dalam mempercepat pertumbuhan zakat di Indonesia. Harta kekayaan perusahaan, zakat profesi, dan kepemilikan saham tidak luput menjadi objek harta kena zakat, hal ini didiskusikan dan diputuskan pada Muktamar ke-3 yang diselenggaran oleh Majelis Ulama Indonesia (MUI) pada tahun 2009 di Sumatera Barat, kemudian pada tahun 2017 gagasan tersebut direalisasikan dengan kesepakatan kerjasama antara Badan Amil Zakat Nasional (BAZNAS), Pasar ModalSyariah Indonesia Bursa Efek Indonesia (PMS-BEI) dalam program Sedekah dan Zakat Saham Nasabah (SAZADAH). Dalam realisasinya, program tersebut membebankan kewajiban zakat kepada akumulasi portofilio investor bukan pada kekayaan perusahaan. Disamping itu program tersebut melibatkan berbagai pihak yang menjadikan alur distribusi zakat menjadi kompleks. Oleh karena itu menarik untuk melihat hubungan relasi sosial di antara pelaku filantropis dalam program SAZADAHdiPMS-BEItersebut. Dengan menggunakan pendekatan teori relasi sosial, artikel ini berkesimpulan bahwa implentasi zakat saham 
di PMS-BEI merupakan relasi yang saling menguntung kedua belah pihak, walaupun pola relasi dalam program tersebut masuk dalam kategori mediatedengagement strategies dengan pola contributory dan brokering philanthropy.

Kata Kunci: Filantropi Islam; Zakat; Saham Syariah;Pasar Modal Syariah.

Abstract: The development of Islamic philanthropic studies in the last few decades has contributed significantly to the expansion of zakat objects implementation. The object of property subject to zakat becomes the focus of discussion by several scholars, religious social institutions, and the government in accelerating the growth of zakat in Indonesia. Company property, professional zakat and share ownership are zakat propertyobjects, this matter was discussed and decided at the 3rd Congress held by the Indonesian Ulama Council (MUI) in 2009 in West Sumatra, then in 2017 the idea realized by a cooperation agreement between the National Amil Zakat Agency (BAZNAS) and the Indonesian Sharia Capital Market Indonesian Stock Exchange (PMS-BEI) in the Customer's Stock Alms and Zakat program (SAZADAH). In its realization, the program imposes zakat obligations on the accumulation of investor portfolios rather than on the company's wealth. Besides that the program involved various parties who made the distribution channel of zakat complex. Therefore, it is interesting to see the relationship of social relations among philanthropic actors in the SAZADAH program on the PMS-BEI. Using a social relations theory approach, this article concludes that the implementation of zakat shares on the PMS-BEI is a mutually beneficial relationship for both parties, even though the pattern of relations in the program falls within the category of mediatedengagement strategies with contributory and philanthropic brokering pattern.

Keywords: Islamic Philanthropy; Zakat; Sharia Stock; Shariah Capital Market.

\section{A. Pendahuluan}

Perkembangan praktik kedermawanan masyarakat muslim beberapa dekade terakhir menarik minat para sarjana untuk mengkaji secara mendalam tentang filantropi Islam. Praktik filantropi dipahami sebagai bentuk tindakan melayani dan memberi secara sukarela kepada orang 
selain dari anggota keluarga dalam artian kolektif. ${ }^{1}$ Penelusuran tentang praktik filantopi Islam ditemukan bahwa pengelolaan zakat di masa Nabi Muhammad SAW dan perkembangan wakaf di Cairo, Mesir pada Abad pertengahan menjadi landasan fundamendal tradisi praktik filantropi dalam dunia Islam. ${ }^{2}$ Tidak hanya berhenti pada masa klasik, tapi lebih dari satu setengah abad para sarjana telah mengklasifikasikan pergeseran bahwa istilah filantropi yang menunjukkan pergerakan ke arah modernitas. ${ }^{3}$

Dalam konteks Indonesia organisasi masyarakat dan lembaga karitas negara dan swasta memberikan corak tersendiri terhadap gerakan filantropi Islam. Muhammadiyah dan Nahdatul Ulama misalnya memiliki divisi khusus dalam mengambangkan dana karitas. ${ }^{4}$ Kemudian gerakan filantropi yang di inisiasi masyarakat akar rumput (grass root) di Indonesia kembali mengemuka pasca orde baru. ${ }^{5}$ Perkembangan lembaga zakat ini tidak lepas dari peran politik pada lembaga pemerintah dan kiprah masyarakat itu sendiri, ${ }^{6}$ walaupun di lain pihak ada pendapat yang menyebutkan bahwa pemerintah absen menghadirkan keadilan sosial dalam memperkuat zakat. ${ }^{7}$ Campur tangan pemerintah akhirnya memunculkan gerakan filantropi dengan berbagai macam bentuk dan model di tengah masyarakat. ${ }^{8}$

Gerakan filantropi tidak hanya berada di lingkaran organisasi sosial keagamaan, akan tetapi gerakan tersebut telah meluas pada ranah privat dan entitas perusahaan komersil. Hal ini menarik minat para sarjana untuk mengkaji hubungan antara filantropis dan objek yang menerima praktik kedermawanan. Seperti identitas bisnis telah memiliki koneksi dengan masyarakat secara sosial yaitu koneksi moral, ${ }^{9}$ dan ditegaskan bahwa fakta sosiologi yang fundamental tentang filantropi adalah terdapat relasi hubungan sosial memberi dan mendapat (giving and gain) antara filantropis dan penerima. ${ }^{10}$ Dengan demikian gerakan tersebut berimplikasi pada tersebarnya perusahaan multinasional besar, menengah, dan kecil diseluruh dunia yang bergerak sebagai agen filantropis. ${ }^{11}$ 
LembagakaritasdiIndonesiajugamengalami perkembangansignifikan yang didanai oleh professional muslim. ${ }^{12}$ Inovasi produk menjadi alat revalitas antar lembaga karitas tersebut. ${ }^{13}$ Berbagai macam bentuk produk karitas digunakan sebagai daya Tarik untuk mengumpulkan dana dari dalam dan luar negeri. Kemudian dana tersebut disalurkan dalam bentuk bantuan cepat tanggap untuk membantu korban bencana alam. ${ }^{14}$ Pertumbuhan lembaga karitas swasta seakan memaksa lembaga zakat yang berada dibawah naungan pemerintah untuk melakukan inovasi dalam pengelolaannya.Beberapa inovasi yang dilakukan adalah memperluas objek harta kena zakat yang di antaranya adalah zakat profesi dan kekayaan perusahaan. ${ }^{15}$ Ijtihad yang dilakukan tersebut mendukung ekspansi harta objek zakat yang telah dilakukan oleh Yusuf Qaradawi yang bependapat bahwa saham dan obligasi merupakan objek zakat yang hukumnya berkisar pada wajib dan tidak wajib. ${ }^{16}$

Gagasan tersebut disambut baik oleh pemerintah Indonesia melalui Badan Amil Zakat Nasional (BAZNAS) dalam rangka memperkuat dan memperluas pengelolaan dan harta kena zakat.Hal ini terlihat dari implementasi gagasan zakat saham di Pasar Modal Syariah Bursa Efek Indonesia (PMS-BEI) tahun 2017. Implementasi gerakan filantropi zakat saham di Pasar Modal Syariah Indonesia diklaim menjadi produk pertama kali di bidang Pasar Modal di dunia.Menjadi menarik bahwa Pasar Modal merupakan tempat bertemunya emiten dan investor yang secara bersama-sama orientasinya profit. Disamping menjadi intermedi dari dua pihak, Pasar Modal melibatkan banyak pihak dalam tataran implementasi, sehingga menyebabkan kompleksitas mekanisme perdagangan saham dan hubungan antara investor dan emiten. Kompleksitas tersebut menyebabkan program Sedekah dan Zakat Saham Nasabah (SAZADAH) juga melibatkan banyak pihak dan memiliki kompleksitas proses pembayaran zakat saham hingga zakat tersebut sampai kepada mustahik.

Dari pemaparan di atas artikel ini melihat bahwa implementasi zakat saham di PMS-BEI melibatkan banyak pihak, sehingga menarik 
untuk mengkaji hubungan relasi social masing-masing pihak. Dengan menggunakan analisis deskriptif dan pendekatan teori relasi sosial yang dikemukakan oleh Ostrander dan Schervisb penulis mencoba untuk melihat bagaimana hubungan antar pelaku filantropi Islam dalam Pasar Modal Syariah di Indonesia?. Pendekatan ini diharapkan dapat memberikan gambaran secara komprehenshif hubungan berbagai lembaga dalam realisasi zakat saham di Pasar Modal Syariah Indonesia. Data yang digunakan dalam artikel ini bersumber data sekunder yang berupa data rilis dari pihak-pihak terkait seperti PMS-BEI, BAZNAS, dan PT. HP Sekuritas sebagai pelaksana implementasi zakat saham tersebut. Kemudian untuk memperkaya analisis dalam artikel ini, penulis juga menganalisis literarur-literatur relevan terkait topik pembahasan. Artikel ini dibagi menjadi beberapa pembahasan, pada bagian awal akan membahas tentang filantropi dalam Islam dalam hal ini adalah zakat. Kemudian akan mengulas terkait perPasar Modalan dan saham Syariah di Bursa Efek Indonesia. Di bagian akhir penulis akan mendialogkan implementasi filantropi zakat saham di Pasar Modal Syariah dengan menggunakan teori relasi social dalam melihat keterkaitan para pihak.

\section{B. Hasil dan Pembahasan}

\section{Filantropi Islam "Zakat"}

Zakat merupakan kewajiban ketiga yang harus ditunaikan oleh umat Islam. Perkembangan segmentasi harta yang wajib dikeluarkan zakatnya telah banyak dibahas oleh para pemikir Islam. Diantaranya Hilman Latief menyebutkan bahwa pembahasan pada seminar dengan tema "zakat kekayaan perusahaan" mencoba untuk mengajukan konsep kepada MUI formulasi konsep zakat korporasi. Menanggapi hal tersebut Kiyai Ma'ruf Amin berpendapat bahwa zakat merupakan representasi keberagamaan individu, sehingga kewajiban zakat harus dibayar oleh personal bukan korporasi. Akan tetapi pada muktamar ke-3 yang diselenggarakan oleh Majelis Ulama Indonesia (MUI) di Padang-Sumatera Barat tahun 2009 memutuskan bahwa korporasi atau perusahaan diwajibkan untuk 
membayar zakat 2,5 persen dari pendapatannya. ${ }^{17}$ Pengembangan harta kena zakat selanjutnya dibahas oleh Hilman Latief yang mengusulkan gaji atau upah menjadi bagian harta kena zakat yang disebut dengan zakat profesi. ${ }^{18}$

Harta kenazakatselanjutnya adalahsaham dan obligasiatau surat tanda kepemilikan hutang. Yusuf Qaradawi berpendapat bahwa implementasi saham dan obligasi diambil dari perusahaan yang modalnya terletak pada perlengkapan, alat-alat, gedung-gedung dan perabotan tidak dipungut dari saham-sahamnya akan tetapi dari keuntungan bersih (net profit) sebesar $10 \% .{ }^{19}$ Islahuddin berpendapat bahwa zakat saham dan obligasi mengerucut kepada tiga hukum yaitu: tidak wajib keduanya karena berasal dari sesuatu yang haram; wajib keduanya bukan dari bunga atau hasil haram dengan nisbah 2,5 persen, dan; wajib keduanya baik modal maupun hasilnya ketika sampai nisab, sektor pertanian 10 atau 5 persen, sedangkan sektor perniagaan 2,5 persen. ${ }^{20}$

Dengan demikian keterjangkauan (deep of reach) lembaga filantropi Islam di Indonesia telah mengalami perluasan, sebab awalnya ia termasuk ruang privat karena dianggap sebagai bentuk tanggung jawab ketaatan personal kepada Allah, kemudian cakupan tersebut meluas kepada sektor publik. Setelah muktamar MUI ke-3 di PadangSumatera Barat, korporasi saat ini diwajibkan untuk mengeluarkan zakat dari pendapatan perusahaan. Disamping itu juga, konsep zakat klasik yang objeknya dibahas oleh para ulama pun mengalami ekspansi. Perkambangan kemudian diarahkan kepada zakat profesi yang saat ini sudah berjalan. Pada November 2017 Pasar ModalSyariah Indonesia meluncurkan produk baru dengan berkolaborasi dengan Badan Amil Zakat Nasional (BAZNAS) yaitu kolaborasi investasi saham dan filantropi Islam khususnya Zakat dan/atau Infaq dalam program yang disebut dengan Sedekah dan Zakat Saham Nasabah (SAZADAH).

Implementasi zakat saham yang dikeluarkan bukan dari pendapatan emiten, akan tetapi dari diambil dari akumulasi portofolio masing-masing 
investor di Pasar Modal Indonesia.Irwan Abdalloh, Kepala Divisi Pasar ModalSyariah Bursa Efek Indonesia (PMS-BEI) menyebutkan bahwa program SAZADAH tersebut memiliki beberapa karakteristik yang sama sekali berbeda dengan zakat yang yang ada di dunia saat ini. Distingsi program SAZADAH diantraya disebutkan bahwa: objek saham kena zakat adalah saham itu sendiri dan bukan dari keuntungan atas transaksi saham; saham yang dimaksud adalah akumulasi portofolio investor atau gabungan dari harta kekayaan seluruhnya, dan; saham kena zakat hanya saham yang terdaftar sebagai saham Syariah. ${ }^{21}$ Perkembangan berbagai aspek objek filantropi Islam pada khususnya zakat membuktikan bahwa political willstakeholder telah sampai pada tahap mengagumkan, karena tanpa dukungan berbagai pihak produk ini tidak dapat diterbitkan begitu saja.

\section{Pasar Modal Indonesia}

Pasar Modal adalah kegiatan yang bersangkutan dengan penawaran umum, perdagangan efek, perusahaan publik yang berkaitan dengan efek yang diterbitkannya, dan lembaga profesi yang berkaitan dengan efek.22Pasar Modal di Indonesia beroperasi di Bursa Efek Indonesia (BEI), BEI adalah pihak yang menyelenggarakan dan menyediakan sistem dan/ atau sarana untuk mempertemukan penawaran jual dan permintaan beli efek, dan pihak lain dengan tujuan memperdagangkan efek di antara mereka. ${ }^{23}$ Pasar Modal Syariah(PMS) adalah Pasar Modal yang mengacu kepada prinsip Syariah. Prinsip Syariah sebagaimana dimaksud adalah prinsip hukum Islam dalam kegiatan Syariah di Pasar Modal berdasarkan fatwa Dewan Syariah Nasional-Majelis Ulama Indonesia (DSN-MUI), sepanjang fatwa tersebut tidak bertentangan dengan Peraturan Otoritas Jasa Keuangan (POJK) dan/atau Peraturan Otoritas Jasa Keuangan lainnya yang didasarkan pada fatwa DSN-MUI. ${ }^{24}$ Dengan demikian Pasar Modal Syariah disamping harus memiliki pedoman kepatuhan Syariah (shariah compliance) dalam bentuk fatwa sebagai acuan operasional, disisi yang lain bahwa fatwa tersebut juga harus tunduk kepada POJK. 
Struktur pada modal Indonesia langsung berada dibawah OJK setelah terbitnya Undang-Undang Nomor 21 Tahun 2011 tentang Otoritas Jasa Keuangan. Pasar Modal Indonesia disebut juga dengan Self Regulation Organization (SRO) atau organisasi yang melaksanakan tingkatkan tertentu dari kewenangan penerapan aturan di industri Pasar Modal. Adapun lembaga SRO di Pasar Modal Indonesia terdiri dari PT. Bursa Efek Indonesia (BEI) ${ }^{25}$, PT. Kustodian Sentral Efek Indonesia (KSEI) ${ }^{26}$ dan PT. Kliring Penjaminan Efek Indonesia (KPEI) ${ }^{27}$. Disamping SRO, yang terlibat sebagai pelaku dalam Pasar Modal Indonesia lainnya adalah Emiten $^{28}$, Perusahaan Efek ${ }^{29}$, Lembaga Penunjang ${ }^{30}$, Profesi Penunjang ${ }^{31}$ dan Investor ${ }^{32}$.

\section{Saham Syariah}

Saham merupakan surat berharga sebagai bukti kepemilikan investor atas suatu perusahaan yang kepemilikannya tidak berbatas waktu. Pendapatan yang didapatkan oleh seorang investor pemegang saham adalah deviden dari perusahaan yang nominalnya selalu mengalami fluktuasi sesuai dengan laba perusahaan. Disampingitu investor akan mendapat capital gain dari selisih harga ketika terjadi transaksi jual beli terhadap saham yang dimiliki. ${ }^{33}$ Dengan demikian memiliki saham dapat disamakan dengan kepemilikan harta kekayaan, sebabsaham akan selalu menjadi hak milik selama saham tersebut tidak diperjual-belikan kepada pihak lain.

Saham merupakan produk yang paling populer dan sering ditransaksikan di Pasar Modal Indonesia. Saham tersebut dibagi menjadi saham Syariah dan saham konvensional. Perbedaan signifikan diantara keduanya adalah terdapat beberapa ketentuan dan proses screening. Hal ini dilakukan dalam rangka penyaringan saham konvensional untuk masuk kedalam daftar saham Syariah. Saham Syariah yang akui dan dapat ditransaksikan di BEI dibagi menjadi dua yaitu saham yang dinyatakan memenuhi kriteria seleksi saham Syariah dan saham yang dicatatkan sebagai saham Syariah oleh emiten. ${ }^{34}$ Dalam rangka 
screening saham Syariah emiten tidak diperkenankan untuk melakukan: perjudian; perdangan yang dilarang; jasa keuangan ribawi; jual beli yang mengandung ketidakpastian; judi; asuransi konvensional; memproduksi, mendistribusi, memperdagangkan dan/atau menyediakan barang atau jasa haram zat, bukan zatnya dan merusak moral atau bersifat mudharat, dan; transaksi yang mengandung unsur suap/riswah. Disamping ketentunan kegitan operasional, emiten juga harus memenuhi rasio keuangan sebagai berikut: total hutang berbasis bunga dibanding total aset tidak lebih dari 45 persen, dan; total pendapatan bunga dan pendapatan tidak halal dibanding dengan total pendapatan usaha dan lainnya tidak lebih dari 10 persen.

Keluar-masuknya saham kedalam Daftar Efek Syariah (DES) diterbitkan oleh OJK secara periodik. Rilis terakhir OJK menyebutkan saham yang terdaftar per Mei 2018 dan dinyatakan efektif sebanyak 381 saham, $^{35}$ namun pada September 2018 jumlah tersebut meningkat menjadi 401 saham $^{36}$ dari 586 perushaan tercatat di Bursa Efek Indonesia atau sekitar 68,4 persen dari total perusahaan go public di BEI adalah saham Syariah. Sedangkan kapitalisasi pasar pada indeks saham Syariah per September 2.072.793,68 milyar untuk Jakarta Islamic Indeks (JII), 3.543.321,48 milyar untuk Indeks Saham Syariah Indonesia (ISSI) dan 2.554.251,94 milyar untuk Jakarta Islamic Indeks 70 (JII 70). ${ }^{37}$ Berdasarkan rilis PT. Kustodian Sentral Efek Indonesia (KSEI) jumlah investor individu di Pasar Modal Indonesia berjumlah 756 ribu Single Investor Identification (SID) yang tercatat, jumlah ini meninngkat 20,6 persen dibanding akhir tahun lalu yang hanya mencapai 630 ribu SID. ${ }^{38}$ Pertumbuhan jumlah investor di Pasar Modal ini kemudian diprediksi akan terus meningkat pada tahun yang akan datang.

Prosedur saham untuk masuk kedalam kategori saham Syariah harus melalui proses seleksi dan pengawasan secara priodik oleh OJK. Proses yang dilalui ini merupakan proses yang harus dilalui oleh emiten. Dilain pihak, Syariah compliance juga dibebankan kepada mekanisme operasional jual beli saham Syariah di BEI. Mekanisme atau tata cara jual 
beli dan transaksi saham Syariah tertuang di dalam Fatwa DSN-MUI dan POJK. ${ }^{39}$ Dengan mekanisme yang sesuai dengan prinsip-prinsip Syariah Islam tentu derivasi yang terkait dengan kepemilikan saham juga harus mengikuti dalam rangka memaksimalkan pencapaian maqasid Syariah.

\section{Mekanisme Zakat Saham di Pasar Modal Indonesia}

Dalam implementasi zakat saham di Pasar Modal Syariah Indonesia terdapat beberapa pihak yang terlibat pada tataran operasional. pertama adalah investor atau pemilik akun saham/portofolio di Bursa Efek Indonesia (BEI). Kemudian pihak sekuritas sebagai broker atau agen yang bentindak atas nama investor dengan menggunakan akad wakalah bil ujrah. Selanjutnya adalah Badan Amil Zakat Nasional (BAZNAS) selaku stakeholder yang memiliki otoritas pendistribusian kumpulan dana zakat.

Perusahaan sekuritas yang diberikan amanah untuk mengurusi produk zakat/infaq saham ini adalah PT. Henan Putihrai Sekuritas (HP Sekuritas) dan berkolaborasi dengan BAZNAS, dimana telah membuka gerai dilantai BEI per 11 Juni $2018 .{ }^{40}$ Gerai saham ini bertujuan agar masyarakat memperoleh informasi Pasar Modal, mekanisme zakat dan sedekah saham serta konsultasi zakat. ${ }^{41}$ Per Juni 2018 jumlah zakat saham yang ada di portofolio BAZNAS sekitar IDR 135 juta zakat saham. ${ }^{42}$

Untuk mengeluarkan zakat saham sebagaimana disebutkan di atas, seseorang tersebut harus menjadi investor di Pasar Modal terlebih dahulu. Untuk menjadi seorang investor di Pasar Modal pertama kali yang harus dilakukan adalah mengubungi Anggota Bursa (AB/ perusahaan sekuritas) dengan membawa Kartu Tanda Penduduk (KTP), Nomor Pokok Wajib Pajak (NPWP), Rekening Bank (RB) dan materai. Kemudian, calon investor akan diminta untuk mengisi formulir yang memuat data-data calon investor, disaat yang bersamaan calon investor mengisi formulir-formulir pembukaan Rekening Dana Nasabah (RDN) pada bank kustodian yang berfungsi sebagai tempat penyimpanan portofolio invenstor. Untuk menjadi investor pada saham Syariah, calon 
investor akan mengisi formulir tambahan. Setelah rangkaian tersebut selesai kemudian membutuh waktu kurang lebih 10 hari kerja untuk memproses RDN dan penerbitan Single Investor Identification (SID). Apabila tahapan tersebut selesai maka calon investor diminta untuk mentransfer sejumlah dana ke RDN calon investor tersebut, kemudian calon investor resmi menjadi investor dan dapat melakukan transaksasi jual beli saham di Pasar Modal.

Intensitas dan aktifitas jual beli saham di Pasar Modal akan selalu dicatat oleh perusahaan sekuritas dan diwajibkan pada setiap bulan juga akan dikirimkan rangkuman portofolio kepada masing-masing investor. Bagi investor yang ingin mengikuti progam Sedekah dan Zakat Saham Nasabah (SAZADAH) dapat mengacu kepada portofolio masing-masing investor dan apabila mencapai ambang batas minimal 85 gram emas maka investor tersebut wajib untuk mengeluarkan zakat. Kemudian menurut buku panduan SAZADAH yang dikeluarkan oleh BAZNAS, HP Sekuritas dan BEI besaran zakat akan dihitung mengikuti sektor dimana bergeraknya perusahaan selama dalam kurun waktu satu tahun. Investor pada sektor retail atau perdagangan dan jasa akan dikenakan zakat sebesar 2,5 persen dari keuntungan bersih (net profit). Investor pada perusahaan sektor penghasil produk bagi konsumen maka mekanisme zakat mengikuti acuan zakat profesi. Kemudian investor pada sektor pertanian akan dikenakan zakat 10 atau 5 persen. Selain itu, apabila perusahaan bergerak pada sektor peternakan maka ketentuan zakatnya tergantung pada jenis hewan ternak. ${ }^{43}$

Apabila investor telah mengetahui jumlah portofolio telah mencapai nisab dan ingin melaksanakan kewajiban zakat dengan saham, maka seorang investor dapat lansung menghubungi pihak HP Sekuritas. Kemudian hasil potongan zakat tersebut akan diserahkan langsung ke rekening Syariah BAZNAS untuk kemudian disalurkan kepada para penerima (mustahik). Kemudian program ini sementara dikhususkan pada saham-saham Syariah yang terdaftar di Indeks Saham Syariah Indonesia (ISSI). ${ }^{44}$ Walaupun zakat dan sedekah saham terkesan rumit 
untuk dilaksanakan karena objek zakat saham yang dikenakan kepada para investor berbasis pada setiap sektor operasional emiten. Akan tetapi dengan kecanggihan tekhnologi saat ini kendala tersebut dapat diminimalisir dengan sistem yang baik. Terlebih zakat saham yang diluncurkan merupakan suatu kemajuan dan perkembagan signifikan untuk mendukung berkembangnya filantropi di Indonesia kedepan.

\section{Relasi Sosial Muzakki dan Mustahik Zakat Saham}

Dalam praktik kegiatan filantropi terdapat beberapa pihak yang terlibat. Yaitu antara donor dan penerima.$^{45}$ Lebih rinci selain kedua pihak tersebut pada praktik zakat saham di Pasar Modal Indonesia terdapat beberapa pihak yang terlibat sebelum sampai kepada mustahik. Diantaranya adalah Bursa Efek Indonesia (BEI), Kustodian Sentral Efek Indonesia (KSEI, Kliring Penjaminan Efek Indonesia (KPEI), PT. Henan Putihrai Sekuritas (HP), dan Badan Amil Zakat Nasional (BAZNAS). Walaupun kompleksitas peran organisasi antara donor dan penerima, hubungan sosial diantara keduanya cenderung memiliki pola yang dapat diidentifikasi. ${ }^{46}$

Strategi relasi sosial dalam filantropi yang dikembangkan oleh Susan yang dibagi menjadi tiga model: ${ }^{47}$ pertama, komunikasi dan kontak antara kedua belah pihak; kedua, pengatahuan spesifik kedua pihak terhadap masing-masing pihak, dan; ketiga, prioritas relatif yang diinginkan oleh donor dengan apa yang dibutuhkan oleh penerima. Dalam praktik zakat saham di Pasar ModalSyariah Indonesia dapat pada strategi pertama antara PT. HP didukungan oleh BEI sebagai konter pengumpulan zakat saham memiliki peran penting untuk melakukan komunikasi kepada pihak muzaki yang ingin membayar zakat atau sedekah dengan saham. Disaat yang bersamaan, peran DSN-MUI memastikan kepada pihak donor kekuatan legal formal bahwasahnya apa akan dilaksanakan telah memenuhi ketentuan sesuai dengan ketentuan Islam.

Adapun peran BAZNAS adalah sebegai mediator dengan para pemerima atau mustahik. Dengan kata lain bahwa, BAZNAS memiliki 
fungsi penyaluran kumpulan zakat atau sedekah atas saham para investor kepada mustahik yang dianggap layak atau berdasarkandelapan asnaf yang telah ditentukan. Pada posisi ini mustahiq tetap akan menerima uang tunai setelah dilakukan widhraw atas zakat saham tersebut, dengan artian para mustahik tidak menerima zakat dalam bentuk saham. Kerjasama antara kedua belah pihak dalam hal ini BEI dan BAZNAS mempunyai mekanisme yang sama sekali berbeda untuk melakukan kontak dan komunikasi kepada masing-masing pihak yang dinaunginya.

Sebagimana dijelaskan sebelumnya bahwa kerjasama antara kedua belah pihak telah melewati kajian yang baik. Kerjasama ini merupakan manifestasi peran lembaga pemerintah untuk menguatkan dan mengembangkan praktik filantropi di Indonesia. Dengan demikian, pengetahuan spesifik dan kredibilitas masing-masing pihak terhadap keduanya telah menjadi unsur yang niscaya. Disamping itu, untuk memenuhi unsur strategi yang ketiga dalam hubungan relasi sosial dalam rangka zakat saham ini adalah masing-masing pihak memastikan sumber zakat saham dan penyaluran tidak lepas dari ketentuan yang berlaku. Sebagai contoh bahwa saham yang masuk dalam kategori wajib zakat adalah merupakan fortopolio yang terdaftar pada Indeks Saham Syariah Indonesia (ISSI). ${ }^{48}$ Pada saat yang bersamaan besaran nominal zakat per sektor diukur secara berbeda, persentase sektor retail akan berbeda dengan sektor pertambangan. Sedangkan posisi BAZNAS dalam strategi yang ketiga adalah memastikan tersalurnya kepentingan muzakki untuk berzakat. Dengan jaringan yang dimiliki yaitu 34 BAZNAS provinsi, 500 BAZNAS kabupaten/kota, 19 Lembaga Amil Zakat (LAZ) nasional, dan 19 Lembaga Zakat Internasional tidak sulit bagi BAZNAS untuk memastikan tersalurnya dana zakat saham dapat terdistribusi dengan baik.

Dari beberapa penjelasan di atas terlihat bahwa hubungan antara muzakki dengan mustahiq merupakan hubungan tidak langsung. Hal ini dikarenakan terdapat beberapa institusi mediari (intermediary institution) yang menghubungkan kedua belah pihak. Dalam kategorisasi strategi 
filantropi disebut dengan "Mediated-Engagement Strategies" atau strategi keterlibatan yang dimediasi. Jenis strategi ini merupakan bentuk kedua dimana penerima diwakili oleh BAZNAS sebagai bentuk advokasi atas nama penerima. Kompleksitas alur keluar - masuk dan perhitungan zakat saham di Pasar ModalSyariah Indonesia hingga sampai kepada mustahik menjadikan peran lembaga mediari disini menjadi sangat penting. Hal ini disebabkan karena butuh teknologi khusus, keterampilan dan pengatahuan rinci untuk mengklasifikasi harga saham, sektor dan sub-sektor perusahaan dan lain sebagainya. Oleh karena ini model pendekatan yang demikian masuk dalam bentuk filantropi kontribusi (contributory philanthropy).

Model relasi sosial dalam praktik zakat saham di Pasar ModalSyariah Indonesia juga dapat masuk kedalam strategi perantara kedermawanan (brokering philanthropy). Brokering Philanthropyyang dimaksud adalah menjadikan organisasi atau pihak-pihak mencurahkan upaya untuk mencari donor. Dalam hal ini adalah PT. HP Sekuritas diberikan mandat oleh BEI untuk menjadi konter penyedia layanan yang bertanggung jawab untuk mengelola, mempromosikan dan berhubungan dengan organisasi kedua dalam hal ini BAZNAS agar mata rantai tersebut tidak terputus.

\section{Kesimpulan}

Ekspansi lembaga filantropi Islam di Indonesia beberapa tahun terakhir tidak lepas dari dukungan stakeholder seperti pemerintah dan lembaga-lembga terkait. Dukungan perluasan objek filantropi Islam di Indonesia muncul pada akhir tahun 2017 yaitu peresmian program zakat saham dengan platform Sedekah dan Zakat Saham Nasabah (SAZADAH). Program tersebut merupakan hasil kolaborasi Badan Amil Zakat Nasional (BAZNAS) dengan Divisi Pasar ModalSyariah Bursa Efek Indonesia (PMS-BEI) dan didukung oleh PT. Bursa Efek Indonesia (BEI), PT. Kustodian Sentral Efek Indonesia (KSEI), Kliring Penjaminan Efek Indonesia (KPEI), Dewan Syariah Nasional Majelis Ulama 
Indonesia (DSN-MUI) serta PT. Henan Putihrai Sekuritas sebagai front liner program SAZADAH. Kolabolasi lembaga-lembaga dalam program tersebut memberikan dampak posisif bagi masing-masing lembaga yang bekerja sama.Dalam konteks hubungan relasi sosial, praktik zakat saham di Pasar Modal Syariah Indonesia merupakan bentuk relasi tidak langsung disebut dengan mediated-engagement strategies. Sedangkan posisi yang diperankan oleh lembaga mediari, baik BAZNAS atau PT. Henan Putihrai Sekuritas dapat dikategorikan pada contributory dan brokering philanthropy. 


\section{Daftar Pustaka}

Capital Market Institute, The Indonesia. “Efek Yang Diperdagangkan

Di Pasar Modal." PPT Material presented at the ToT Workshop, Jakarta, 2017.

Fauzia, Amelia. "Faith and The State: A History of Islamic Philanthropy in Indonesia." Ph. D Thesis, The Asia Institute, The University of Melbourne, 2008.

Fauziyah, Ririn. "Pemikiran Yusuf Qardhawi Mengenai Zakat Saham Dan Obligasi." Jurisictie: Jurnal Hukum Dan Syariah 1, no. 2 (2010): 69-79.

Gautier, Arthur, and Anne Claire Pache. "Reserach on Corporate Philanthropy: A Review and Assesment." Journal of Business Ethics 126, no. 3 (2013): 343-69.

Hassan, Riaz. "Giving and Gaining: Philanthropy and Social in Muslim Society." Lahore Journal of Policy Studies 1, no. 1 (2007): 25-34.

Ilcman, Warren F, Stanley N Katz, and Edward L Queen II. Philanthropy in The World's Traditions. Vol. 91. Bloomington: Indiana University Press, 1998.

Jasa Keuangan, Otoritas. Keputusan Dewan Komisioner Otoritas Jasa Keuangan Republik Indonesia, Pub. L. No. Kep-24/D.04 (2018).

- - - Peraturan Otoritas Jasa Keuangan Republik Indonesia Tentang Akad yang Digunakan dalam Penerbitan Efek Syariah di Pasar Modal, Pub. L. No. 53, 04 POJK (2015).

- - - Peraturan Otoritas Jasa Keuangan Republik Indonesia Tentang Penerapan Prinsip Syariah di Pasar Modal, Pub. L. No. 15, 04 POJK (2015).

Kasdi, Abdurrohman. "Filantropi Islam Untuk Pemberdayaan Ekonomi Umat (Model Pemberdayaan ZISWAF Di BMT Se-Kabupaten 
Demak)." Iqtishodia 9, no. 2 (2016): 227-45.

Latief, Hilman. "Contesting Almsgiving in Post-New Order Indonesia." The American Journal of Islamic Social Sciences 31, no. 1 (2014): 16-50.

- - - "Islamic Charities and Dakwah Movement in a Muslim Minority Island: The Experience of Niasan Muslims." Journal of Indonesian Islam 6, no. 2 (2014): 221-44.

- - . "Islamic Philanthropy and The Private Sector in Indonesia." Indonesian Journal of Islam and Muslim Societies 3, no. 2 (2013): 175201.

- - - Melayani Umat: Filantropi Islam Dan Ideologi Kesejahteraan Kaum Modernis. Jakarta: Gramedia Pustaka Utama, 2010.

Mubarak, Islahuddin Ramadhan. "Zakat Saham Dan Obligasi (Studi Analisis Istinbat Hukum Yusuf Al-Qardawi)." Master Thesis, Universitas Islam Negeri Alauddin Makasar, 2017.

Muhtada, Muhtada. "Islamic Philanthropy and The Third Sector: The Potrait of Zakat Organizations in Indonesia." Islamika Indonesiana 1, no. 1 (2014): 106-23.

Ostrander, Susan A, and Paul G Schencish. "Giving and Getting: Philanthropy as a Social Relation." In Woman, Philanthropy and Social Change: Vision for A Justice Society. Lebanon: University Press of New England, 2005.

Pasar ModalSyariah, Direktorat. "Statistik Pasar ModalSyariah." Jakarta: Direktorat Pasar ModalSyariah Otoritas Jasa Keuangan, 2018.

Retrikas, Konstantinos. "Reconceptualising Zakat in Indonesia: Worship, Philanthropy and Rights." Indonesia and Malay World 42, no. 124 (2014): 337-57.

Shaikh, Salman Ahmad, Mohd Adib Ismail, and Abdul Ghafar Ismail. "Exploring Dinamics of Private Giving as Income Support Institution for Endowment Deficient Consumers." Journal of Islamic 
Economics, Banking and Finance 14, no. 1 (2018): 147-67.

Shaw, Bill, and Frederick R Post. "A Moral Basis for Corporate Philanthropy." Journal of Business Ethics 12, no. 10 (1993): 745-51. Syariah Nasional, Dewan. Fatwa Dewan Syariah Nasional Tentang Pasar Modal dan Pedoman Umum Penerapan Prinsip Syariah di Bidang Pasar Modal, Pub. L. No. 40, X DSN-MUI (2003).

- - - Fatwa Dewan Syariah Nasional Tentang Penerapan Prinsip Syariah dalam Mekanisme Perdagangan Efek Bersifat Ekuitas di Pasar Reguler Bursa Efek, Pub. L. No. 80, III DSN-MUI (2011).

Widyawati. Filantropi Islam Dan Kebijakan Negara Pasca-Orde Baru: Studi Tentang Undang-Undang Zakat Dan Undang-Undang Wakaf. 1st ed. Bandung: Arsad Press, 2011.

Yumna, Aimatul. “Understanding Sustainability and Outreach of Islamic Charity Based Microfinance: Case Study in Indonesia." Ph. D Thesis, Deakin University, 2014.

\section{Internet}

Abdalloh, Irwan. "Islamic Stock-Based Zakat in Indonesia." Islamic Finance News, 2018.

Hilmi, Alfan. "Zakat Saham, Ini Pernjelasan MUI Yang Perlu Diketahui."

News Portal. www.tempo.co (blog), 2017.Diaksespadatanggal 9 Februari 2019.

Munir, Misbahol. "Ada Gerai Zakat Saham Di BEI." News Portal. www. msn.com (blog), 2018.Diaksespadatanggal 9 Februari 2019.

Simamora, Novita Sari. "Zakat Saham Mulai Mengalir Dari Investor Pasar Modal." News Portal. www.m.bisnis.com (blog), 2018. Diaksespadatanggal 10 Februari 2019.

Wareza, Monica. "Jumlah Investor Individu Di Pasar Modal 756 Ribu." News Portal. www.cnbcindonesia.com, September 9, 2018. Diaksespadatanggal 10 Februari 2019 


\section{Endnotes}

1. Warren F Ilcman, Stanley N Katz, and Edward L Queen II, Philanthropy in The World's Traditions, vol. 91 (Bloomington: Indiana University Press, 1998), xi.

2. Amelia Fauzia, "Faith and The State: A History of Islamic Philanthropy in Indonesia" (Ph. D Thesis, Melbourne, The Asia Institute, The University of Melbourne, 2008), 27.

3. Ilcman, Katz, and Queen II, 91:3.

4. Hilman Latief, Melayani Umat: Filantropi Islam Dan Ideologi Kesejahteraan Kaum Modernis (Jakarta: Gramedia Pustaka Utama, 2010).

5. Widyawati, Filantropi Islam Dan Kebijakan Negara Pasca-Orde Baru: Studi Tentang Undang-Undang Zakat Dan Undang-Undang Wakaf, 1st ed. (Bandung: Arsad Press, 2011).

6. Fauzia, "Faith and The State: A History of Islamic Philanthropy in Indonesia."

7. Riaz Hassan, "Giving and Gaining: Philanthropy and Social in Muslim Society," Lahore Journal of Policy Studies 1, no. 1 (2007): 25-34.

8. Konstantinos Retrikas, "Reconceptualising Zakat in Indonesia: Worship, Philanthropy and Rights," Indonesia and Malay World 42, no. 124 (2014): 337-57; Aimatul Yumna, "Understanding Sustainability and Outreach of Islamic Charity Based Microfinance: Case Study in Indonesia" (Ph. D Thesis, Melbourne, Deakin University, 2014); Abdurrohman Kasdi, “Filantropi Islam Untuk Pemberdayaan Ekonomi Umat (Model Pemberdayaan ZISWAF Di BMT Se-Kabupaten Demak)," Iqtishodia 9, no. 2 (2016): 227-45; Salman Ahmad Shaikh, Mohd Adib Ismail, and Abdul Ghafar Ismail, "Exploring Dinamics of Private Giving as Income Support Institution for Endowment Deficient Consumers," Journal of Islamic Economics, Banking and Finance 14, no. 1 (2018): 147-67.

9. Bill Shaw and Frederick R Post, "A Moral Basis for Corporate Philanthropy," Journal of Business Ethics 12, no. 10 (1993): 745-51.

10. Susan A Ostrander and Paul G Schencish, "Giving and Getting: Philanthropy as a Social Relation," in Woman, Philanthropy and Social Change: Vision for A 
Justice Society (Lebanon: University Press of New England, 2005), 68.

11. Arthur Gautier and Anne Claire Pache, "Reserach on Corporate Philanthropy: A Review and Assesment," Journal of Business Ethics 126, no. 3 (2013): 343-69.

12. Hilman Latief, "Islamic Philanthropy and The Private Sector in Indonesia," Indonesian Journal of Islam and Muslim Societies 3, no. 2 (2013): 175-201.

13. Muhtada Muhtada, "Islamic Philanthropy and The Third Sector: The Potrait of Zakat Organizations in Indonesia," Islamika Indonesiana 1, no. 1 (2014): 106-23.

14. Hilman Latief, "Islamic Charities and Dakwah Movement in a Muslim Minority Island: The Experience of Niasan Muslims," Journal of Indonesian Islam 6, no. 2 (2014): 221-44.

15. Latief, "Islamic Philanthropy and The Private Sector in Indonesia."

16. Islahuddin Ramadhan Mubarak, “Zakat Saham Dan Obligasi (Studi Analisis Istinbat Hukum Yusuf Al-Qardawi)" (Master Thesis, Makasar, Universitas Islam Negeri Alauddin Makasar, 2017), 37-40.

17. Latief, "Islamic Philanthropy and The Private Sector in Indonesia."

18. Hilman Latief, "Contesting Almsgiving in Post-New Order Indonesia," The American Journal of Islamic Social Sciences 31, no. 1 (2014): 16-50.

19. Ririn Fauziyah, "Pemikiran Yusuf Qardhawi Mengenai Zakat Saham Dan Obligasi," Jurisictie: Jurnal Hukum Dan Syariah 1, no. 2 (2010): 69-79.

20. Mubarak, "Zakat Saham Dan Obligasi (Studi Analisis Istinbat Hukum Yusuf Al-Qardawi)," 40-43.

21. Irwan Abdalloh, "Islamic Stock-Based Zakat in Indonesia," Islamic Finance News, 2018.

22. Dewan Syariah Nasional, "Fatwa Dewan Syariah Nasional Tentang Pasar Modal Dan Pedoman Umum Penerapan Prinsip Syariah Di Bidang Pasar Modal," Pub. L. No. 40, X DSN-MUI (2003).

23. Dewan Syariah Nasional, "Fatwa Dewan Syariah Nasional Tentang Penerapan Prinsip Syariah Dalam Mekanisme Perdagangan Efek Bersifat Ekuitas Di Pasar Reguler Bursa Efek," Pub. L. No. 80, III DSN-MUI (2011). 
24. Otoritas Jasa Keuangan, "Peraturan Otoritas Jasa Keuangan Republik Indonesia Tentang Penerapan Prinsip Syariah Di Pasar Modal," Pub. L. No. 15, 04 POJK (2015).

25. Didirikan dengan tujuan menyelenggarakan perdagangan efek yang teratur, wajar dan efisien serta menyediakan sarana pendukung, mengawasi anggota bursa, menyusun anggaran tahunan, penggunaan laba dan bertanggung jawab kepada otoritas.

26. Lembaga Penyimpanan dan Penyelesaian (LPP), pihak yang menyelenggarakan kegiatan kustodian sentral bagi bank kustodian, perusahaan efek dan pihak lain.

27. Pihak yang mendapatkan izin sebagai Lembaga Kliring dan Penjaminan (LKP) penyelesaian transaksi bursa. Dalam artian proses penentuan hak dan kewajiban efek dan/atau dana anggota bursa yang timbul dari transaksi efek yang dilakukan di bursa efek.

28. Perusahaan yang menghimpun dana dari masyarakat dengan menjual atau menawarkan efek kepada publik, yang dikenal dengan istilah penawaran umum perdana/initial public offering (IPO)/go public.

29. Adalah perseroan yang telah memperoleh izin usaha dari OJK dan dapat melakukan kegiatan sebagai Penjamin Emisi Efek (WPE), Perangtara Perdagangan Efek (PPE) dan/atau Manajer Investasi (MI).

30. Terdiri dari Biro Administrasi Efek (BAE), Bank Kustodian, Wali Amanat, Pemeringkat Efek, Penilai Harga Efek, Indonesia Secirities Investor Protection Fund (SIPF) dan The Indonesia Capital Market Institute (TICMI).

31. Akuntan, Konsultan Hukum, Penilai, Notaris dan Profesi lain yang ditetapkan dengan Peraturan Pemerintah.

32. Adalah para pemilik modal yang menginvestasikan dananya di Bursa Efek Indonesia dengan mekanisme yang telah ditentukan.D

33. The Indonesia Capital Market Institute, “Efek Yang Diperdagangkan Di Pasar Modal" (PPT Material, ToT Workshop, Jakarta, 2017).

34. Otoritas Jasa Keuangan, “Peraturan Otoritas Jasa Keuangan Republik Indonesia Tentang Akad Yang Digunakan Dalam Penerbitan Efek Syariah Di Pasar Modal," Pub. L. No. 53, 04 POJK (2015). 
35. Otoritas Jasa Keuangan, "Keputusan Dewan Komisioner Otoritas Jasa Keuangan Republik Indonesia," Pub. L. No. Kep-24/D.04 (2018).

36. Direktorat Pasar ModalSyariah, "Statistik Pasar ModalSyariah" (Jakarta: Direktorat Pasar ModalSyariah Otoritas Jasa Keuangan, 2018).

37. Pasar ModalSyariah.

38. Monica Wareza, “Jumlah Investor Individu Di Pasar Modal 756 Ribu," News Portal, www.cnbcindonesia.com, September 9, 2018.

39. Syariah Nasional, Fatwa Dewan Syariah Nasional Tentang Penerapan Prinsip Syariah dalam Mekanisme Perdagangan Efek Bersifat Ekuitas di Pasar Reguler Bursa Efek; Jasa Keuangan, Peraturan Otoritas Jasa Keuangan Republik Indonesia Tentang Akad yang Digunakan dalam Penerbitan Efek Syariah di Pasar Modal.

40. Misbahol Munir, "Ada Gerai Zakat Saham Di BEI," News Portal, wwww.msn. Com (blog), 2018.

41. Munir.

42. Novita Sari Simamora, "Zakat Saham Mulai Mengalir Dari Investor Pasar Modal," News Portal, www.m.Bisnis.Com (blog), 2018.

43. Alfan Hilmi, “Zakat Saham, Ini Pernjelasan MUI Yang Perlu Diketahui," News Portal, www.tempo.co (blog), 2017.

44. Hilmi.

45. Ostrander and Schencish, "Giving and Getting: Philanthropy as a Social Relation," 69.

46. Ostrander and Schencish, 70.

47. Ostrander and Schencish, 77-91.

48. Hilmi, "Zakat Saham, Ini Pernjelasan MUI Yang Perlu Diketahui." 